\title{
Modelos animais ajudando a decifrar doenças neuromusculares humanas
}

\section{Animal models of neuromuscular disorders}

Mariz Vainzof ${ }^{1}$, Lydia U Yamamoto ${ }^{1}$, Patrícia M Kossugue ${ }^{1}$, Luciana LQ Fogaça $^{1}$, Fernando Z Velloso ${ }^{1}$, Danielle Ayub ${ }^{1}$, Viviane $P$ Muniz $^{1}$, Mayana Zatz $^{1}$, Helga CA Silva ${ }^{1}$, Silvia MG Massironi ${ }^{2}$, Maria Angélica Miglino ${ }^{3}$, Carlos Eduardo Ambrosio ${ }^{3}$, Ligia G Miyazato ${ }^{4}$, Julieta RE Moraes, Fernando HF D'Angeles ${ }^{4}$, Joaquim C Lacerda Neto ${ }^{4}$, Ana Carolina Mortari $^{5}$, Alexandre S Borges ${ }^{5}$, Luiz antonio L Rezende ${ }^{5}$, Sheila C Rahal ${ }^{5}$

1-) Centro de Estudos do Genoma Humano, IBUSP, 2) ICB, USP, 3-) FMVZ, USP; 4) FCAV-UNESP, Jaboticabal; 5-) FMVZ e FM-UNESP, Botucatu, SP.

As afecções neuromusculares humanas constituem um grupo heterogêneo de doenças genéticas caracterizadas por degeneração muscular progressiva, levando ao desenvolvimento de fraqueza muscular e perda de capacidade motora. Na última década, foram identificadas mutações em vários genes, resultando na deficiência ou perda de função de diversas proteínas musculares de importância significativa para o bom funcionamento do músculo. Estudos bioquímicos e imunohistológicos têm localizado estas proteínas nos diversos compartimentos da fibra muscular. Associadas à membrana sarcolemal, encontram-se a distrofina, as 4 sarcoglicanas, disferlina e caveolina 3; na matriz extracelular, a $\alpha 2$-laminina e colágeno VI; nos sarcômeros, a teletonina, miotilina, titina, actina e tropomiosina; no citosol muscular, canal de Cálcio (receptor de rianodina), a calpaina 3, FRPR, TRIM32, miotubularina; e nos núcleos, a emerina, lamina A/C, proteína SMN. Algumas das doenças associadas a alterações nestas proteínas são as distrofias musculares progressivas e as miopatias congênitas.

Estudos clínicos e neurológicos em animais com fraqueza muscular têm ajudado a identificar alguns modelos animais tais como camundongos, cães e gatos, deficientes para diferentes proteínas musculares. Os estudos realizados nestes animais são cruciais para aumentar nossos conhecimentos a respeito de doenças genéticas humanas e para a investigação de terapias experimentais. A facilidade com que o genoma murino pode ser manipulado faz do camundongo uma ferramenta bastante utilizada em testes moleculares e na avaliação de complexos protéicos musculares. Dentre os modelos murinos, o camundongo $m d x$, apresenta uma mutação de ponto no gene da distrofina, e uma ausência total da proteína 
no músculo, constituindo um modelo molecular e protéico para a distrofia muscular de Duchenne humana (DMD). Diversos camundongos transgênicos e knockout para as proteínas sarcoglicanas, caveolina e disferlina já foram gerados, e estão ajudando no estudo dos mecanismos de composição e funcionamento destes complexos protéicos nos animais afetados.

Devido à deficiência da proteína distrofina, como em pacientes com DMD, o músculo de camundongos $m d x$ é afetado por degeneração e necrose. Entretanto, o camundongo $m d x$ exibe um curso clínico mais brando. Além disso, a fraqueza muscular não é característica e o tempo de vida não é reduzido. Esse camundongo também apresenta um grande número de fibras revertentes (2-3\%), que passam a sintetizar novamente de forma espontânea a distrofina. Como a presença natural destas fibras dificulta a análise de terapias que visam a expressão de distrofias, outros modelos murinos de DMD foram experimentalmente induzidos. Embora o camundongo mdx seja um bom modelo molecular, não é um bom modelo clínico, por não apresentar fraqueza muscular significativa, dificultando o seu uso na avaliação clínica da eficácia de triagens terapêuticas . Neste sentido, a identificação do modelo canino da raça Golden Retriever com deficiência de distrofina trouxe novas perspectivas, uma vez que apresenta fraqueza muscular significativa, simulando a distrofia humana. A patogênese do GRMD tem manifestação in utero com o desenvolvimento de lesões musculares linguais. Extensas necroses dos músculos dos membros, tronco e pescoço podem ser identificadas já ao nascimento. Assim como na doença humana e no modelo $m d x$, as concentrações da enzima creatino quinase sérica estão também extremamente elevadas desde o nascimento. Em seis meses, desenvolvem-se fibrose muscular e contraturas nas junções. Além disso, cães jovens com GRMD podem também morrer por falha cardíaca ou respiratória, embora alguns sobrevivam e alcancem muitos anos de vida. Diversos estudos de terapia gênica e celular estão em andamento no modelo canino da distrofia de Duchenne.

Estudos moleculares em modelo porcino contribuíram significativamente na descoberta do principal gene envolvido na hipertermia maligna humana. A partir da identificação de uma mutação neste mesmo gene em porcos com crises semelhantes à HM humana, desencadeadas por estresse, denominada Síndrome do estresse suíno (PSS - Porcine Stress Syndrome), foi possível localizar o gene RYR1 humano no cromossomo 19. Para melhor investigar o efeito de alterações neste importante canal de cálcio, foram gerados em 1998 camundongos mutantes, onde dois genes, RYR1 e RYR3 foram inativados. Verificouse que o músculo esquelético de animais duplo mutantes não se contraía em resposta à cafeína 
ou rianodina e também apresentava diversas alterações histológicas, sugerindo degeneração miofibrilar. Isto foi confirmado por análises bioquímicas das proteínas contráteis, e o estudo ultraestrutural confirmou a presença de miofibrilas reduzidas com completa ausência de receptores de rianodina nas junções do retículo sarcoplasmático.

Para o estudo do mecanismo de funcionamento das diversas outras proteínas envolvidas nas doenças neuromusculares humanas, faz-se necessário identificar novos modelos animais com fraqueza muscular, triados em diversos Centros Veterinários. Para tal, estão sendo feitos estudos histológicos, histoquímicos, imunohistoquímicos e de western blot em biópsias musculares de animais com fraqueza muscular. A identificação e caracterização de modelos animais com deficiências musculares semelhantes às descritas nas doenças humanas constituem importante ferramenta para a avaliação fisiopatológica do respectivo defeito molecular primário. Além disso, podem ter um papel significativo como modelo bioquímico e clínico para ensaios terapêuticos.

\section{Referências}

1. Allamand V, Campbell KP. Animal models for muscular dystrophy: valuable tools for the development of therapies. Human Mol Genet 2000; 9: 2459-2467.

2. Barone V, Bertocchini F, Bottinelli R, et al. Contractile impairment and structural alterations of skeletal muscles from knockout mice lacking type 1 and type 3 ryanodine receptors. FEBS Lett 1998; 422:160-164.

3. Cooper BJ, Winand NJ, Stedman H, et al. The homologue of the Duchenne locus is defective in Xlinked muscular dystrophy of dogs. Nature 1988; 334: 154-156.

4. Fujii J, Otsu K, Zorzato F, et al. Identification of a mutation in porcine ryanodine receptor associated with malignant hyperthermia. Science 1991; 253: 448-451.

5. Gussoni E, Yko S, Strickland CD, et al. Dystrophin expression in the $m d x$ mouse restored by stem cell transplantation. Nature 1999; 401: 390-394.

6. Pastoret C, Sebille A. $M d x$ mice show progressive weakness and muscle deterioration with age. J Neurol Sci 1995; 129: 97-105.

7. Vainzof M, Yamamoto LU, Gouveia TLF, Zatz M. The contribution of protein analysis in the diagnosis of neuromuscular diseases. In: Burgess VN, Trends in Muscular Dystrophy Research. USA: Nova Publisher, 2005. 